\title{
Não é fumaça, é fogo! Cruzada antigênero e resistências feministas no Brasil
}

\author{
Flávia Melo' (iD) 0000-0002-3179-5294 \\ 'Universidade Federal do Amazonas, Programa de Pós-Graduação em Antropologia, \\ Manaus, AM, Brasil. 69080-900 - ppgascoordenacao@ufam.edu.br
}

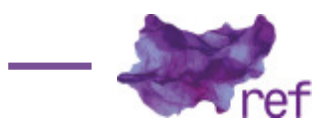

Resumo: Eventos recentes posicionaram o gênero no cerne da vida pública brasileira. Neste artigo, descrevo dois processos imbricados a isso: a cruzada antigênero e a eclosão da "primavera feminista". A primeira, estratégia católica transnacional, emergiu no Brasil em 2014. Anos depois, parlamentares pró-impeachment declararam votos em favor da família e contra a "ideologia de gênero" - expressão habilmente apropriada por uma poderosa coalizão dentro e fora do parlamento. Em 2018, a campanha antigênero voltou aos debates nacionais com a candidatura de Jair Bolsonaro à presidência. O rechaço ao candidato agregou milhares de mulheres nas redes sociais e nas ruas, formando o movimento \#elenão. Porém, não se tratava de reação repentina ou inédita: as resistências das mulheres têm demonstrado a potência de suas alianças e contestado a tese da "cortina de fumaça" que rotula as táticas do atual governo.

Palovras-chave: cruzada antigênero; feminismos; conservadorismos; religião.

It's Not Smokes, It's Firel Anti-Gender Crusade and Feminist Resistances in Brazil

Abstract: Recent events positioned the gender in the heartwood of Brazilian public life. In this article, I describe two processes imbricated to it: the anti-gender crusade and the outbreak of the "feminist spring". The first, a transnational Catholic strategy, emerged in 2014. Years later, pro-impeachment parliamentarians cast votes in favour of the family and against the "gender ideology" - expression appropriated by a powerful coalition inside and outside parliament. In 2018, the anti-gender campaign returned to national debates with Jair Bolsonaro running for president. The rejection of the candidate aggregated thousands of women in social networks and in the streets, forming the \#elenão movement. But this was not a sudden or unprecedented reaction: women's resistance has demonstrating the potency of their alliances and challenging the "smoke screen" thesis that labels the tactics of the current government.

Keywords: Anti-gender Crusade; Feminisms; Conservatism; Religion.

\section{Cruzadas, Resistências e Fogo}

Acontecimentos intensificados no último quinquênio revelaram como os embates em torno dos direitos sexuais e reprodutivos passaram a ocupar lugar cada vez mais central na vida pública brasileira. Comumente consideradas como atinentes a "questões comportamentais", "pautas identitárias" ou "de costumes" (Tatiana MAIA, 2018; Vitor FERNANDES, 2018; Luis CALGANO; Maria Eduarda CARDIM, 2019; Rafael MOURA; Amanda PUPO, 2019), as questões de gênero e sexualidade desempenharam papel decisivo nas recentes disputas da política nacional, tendo exercido grande influência no último processo eleitoral do país.

A reificação da família "tradicional" como modelo hegemônico e excludente; a perseverante e capilar ação religiosa para a produção da categoria política "ideologia de gênero" (Flávia MELO, 2016; MELO; Fabio Magalhães CANDOTTI, 2017); e a propagação do pânico moral (Gayle RUBIN, 1993; MISKOLCI; CAMPANA, 2017; Manuel Alejandro Rodríguez RONDÓN, 2017; Rafaela BORGES; Zulmira BORGES, 2018; Fernando BALIEIRO, 2018; Rogério JUNQUEIRA, 2018) foram componentes fundamentais para a coalizão que tornou possível a ascensão do candidato do 
Partido Social Liberal (PSL) à presidência do Brasil em 2018. Contudo, sabemos, a "reemergência da direita" (Luis Felipe MIGUEL, 2016; 2018) não se trata de fenômeno nacional, recente ou isolado. Em muitas outras partes do mundo assistimos ao crescimento das direitas populistas (Michael LÖWY, 2015; Débora MESSENBERG, 2017; Sara GARBAGNOLI; Massimo PREARO, 2017; Roman KUHAR; David PATERNOTTE, 2018), dos ataques antigênero e aos efeitos destes últimos em decisões políticas que extrapolam - e em muito - o escopo das reivindicações identitárias ou pelo reconhecimento de direitos sexuais e reprodutivos, revelando os contornos de um movimento transnacional (GARBAGNOLI, 2014; Mónica CORNEJO-VALLE; José Ignacio PICHARDO, 2017; KUHAR; PATERNOTTE, 2018; Marco Aurélio PRADO; Sonia CORRÊA, 2018; Marta C. FERNANDÉZ, 2019) que localmente se conecta a outras forças reacionárias.

Em maio de 2016, o então presidente mexicano Enrique Peña Nieto apresentou um projeto de alteração constitucional para o reconhecimento da união homoafetiva no México. A iniciativa provocou grande mobilização contrária no país. Na ocasião, a expressão "ideologia de gênero" foi amplamente empregada pelo discurso oposicionista. Organizações religiosas convocaram a união dos países latino-americanos para o fortalecimento da Frente Latinoamericana por el Derecho a la vida y a la Família. Em setembro do mesmo ano, em diferentes cidades mexicanas, realizaram-se atos em defesa da família, bradando frases como "iNo con mis hijos!". Em novembro, a emenda à constituição mexicana foi finalmente rejeitada pela maioria dos congressistas. Dentre os partidos contrários à proposta estavam o Ação Nacional (PAN) e o Verde (PVEM), declaradamente católicos, e o Partido Encontro Social (PES), o "partido da família" (SEMANA, 2016; Ariel PALACIOS, 2019). ${ }^{1}$

Outro exemplo paradigmático ocorreu na Colômbia, por ocasião do plebiscito para ratificar o acordo de paz entre as Forças Armadas Revolucionárias-Exército do Povo (FARC-EP) e o governo colombiano (Mara Viveros VIGOYA et al., 2017). Recusado em outubro de 2016, o acordo foi rechaçado pela Igreja Católica em razão dos termos do processo de paz que garantiriam a igualdade de condições para todas as pessoas, independente de orientação sexual ou identidade de gênero (ACIPRENSA, 2016). Tais premissas consideravam o fato de as mortes de pessoas LGBT serem 40 vezes maiores entre as vítimas do conflito armado (Camila MUELLE, 2017). No entanto, organizações religiosas colombianas recusaram-nas e reivindicaram sua alteração para "incluir as organizações religiosas como grupos vulneráveis sujeitos a apoio especial e eliminar a caracterização velada de grupos LGTI (sic) como grupos historicamente discriminados" (ACIPRENSA, 2016).

Embora existam registros mais remotos em outras partes do mundo - como Peru (Oscar ALZAMORA REVOREDO, 1998), Argentina (Jorge SCALA, 2010), Espanha (CORNEJO-VALLE; PICHARDO, 2017), Itália e França (KUHAR; PATERNOTTE, 2018) -, no Brasil, a difusão da expressão "ideologia de gênero" - estratégia retórica performatizada nos ataques transnacionais aos estudos de gênero emergiu exemplarmente em 2014, durante a aprovação do Plano Nacional de Educação (Lei 13005/2014 [BRASIL, 2014]). No processo de impeachment presidencial em 2018, a expressão voltou ao Congresso Nacional, compondo o repertório de parlamentares favoráveis à deposição de Dilma Rousseff. Contudo, foi nas eleições presidenciais de 2018 que a "ideologia de gênero" passou a ocupar o centro dos principais debates sobre a vida pública nacional, sendo eficazmente utilizada por grupos políticos religiosos, seculares e de extrema-direita, como o Programa Escola Sem Partido (ESP), ${ }^{2}$ o Movimento Brasil Livre $(\mathrm{MBL})^{3}$ e o Revoltados On-Line. ${ }^{4}$

Assim, a expressão oriunda de uma estratégia católica em curso desde o final dos anos 1990 (JUNQUEIRA, 2018; KUHAR; PATERNOTTE, 2018) - e progressivamente difundida por uma série crescente de publicações (Joseph RATZINGER, 1997; Dale O'LEARY, 1997; ALZAMORA REVOREDO, 1998; PONTIFICIO CONSIGLIO PER LA FAMIGLIA, 2006; PAPA BENTO XVI, 2008; SCALA, 2010; Nicolás MÁRQUEZ; Agustín LAGE, 2016) - , no Brasil, foi habilmente apropriada e difundida por parlamentares

\footnotetext{
' Segundo as fontes citadas, um dos opositores ao reconhecimento da união homoafetiva no México foi a Organización Nacional del Yunque, organização católica de extrema-direita cuja face mais visível é a Frente Nacional por la Familia, que conta com apoio parlamentar nos principais partidos políticos do país.

${ }^{2}$ Criado em 2004 por movimento homônimo inspirador dos projetos de lei 7180/2014, 867/2015 e 193/2016. Os projetos propunham mudanças na Lei de Diretrizes e Bases da Educação (Lei 9394/1996) para garantir "o respeito pelas convicções e pelos valores morais e religiosos dos estudantes e de suas famílias"; implementar o ESP; e proibir a "ideologia de gênero". Após tentativas frustradas de aprovação, as propostas foram arquivadas em novembro de 2018. Mas duas novas propostas (246/2019 e 258/2019) foram apresentadas à Câmara Federal por Bia Kicis (PSL) e o Pastor Eurico (Partido Patriota-PATRI) em 2019.

${ }^{3}$ Surgiu em 2014 como um movimento em defesa do liberalismo econômico. Dois de seus principais líderes são parlamentares: Fernando Holiday, do Partido Democrata (DEM) - vereador mais jovem eleito pelo município de São Paulo (2017-2020) - e Kim Kataguiri (DEM) - o $4^{\circ}$ deputado mais votado para a Câmara Federal em 2018. Entre as propostas defendidas pelo MBL estão o ESP, a militarização das escolas, a privatização do sistema de saúde, presídios e transporte público. Disponível em http://mbl.org.br. Acesso em 13/05/2019.

${ }^{4}$ Surgiu em 2000 para denunciar pedófilos nas redes sociais. Em 2010, engajou-se a favor do impeachment. Seu fundador, Marcello Reis, candidatou-se em 2018, não sendo eleito. Alexandre Frota, hoje no Partido da Social Democracia Brasileira (PSDB), outro político associado ao grupo, elegeu-se deputado federal pelo PSL (2019-2022).
} 
da Frente Parlamentar Evangélica e diferentes grupos políticos alinhados à direita, o que permitiu uma emblemática e bem-sucedida coalizão dentro e fora do parlamento (Jairo Antonio LÓPEZ, 2018). ${ }^{5}$ Mas isso não ocorreu sem resistências.

Nas casas legislativas, nas redes sociais e nas ruas de todo o país, formas de resistência e aliança eram gestadas por mulheres, movimentos feministas e LGBT. As audiências públicas sobre os planos de educação, iniciadas em 2014, caracterizaram-se por debates calorosos e enfrentamentos hostis entre grupos favoráveis e contrários aos estudos de gênero. Na cidade de Manaus, onde participei dos debates sobre os planos municipal e estadual, nosso pequeno grupo pró-gênero disputava lugar e voz nas plenárias com centenas de cristãos, majoritariamente católicos da Renovação Carismática Católica, que, entre orações, terços e bíblias, aspergiam água benta e apoiavam as emendas de parlamentares evangélicos e católicos antigênero. Uma vereadora católica do Partido dos Trabalhadores justificou na plenária o seu voto: "Deus não fez Adão e Ivo!".

No ano de 2015, a indignação causada pelos insultos sexuais dirigidos a uma participante do programa televisivo Master Chef Kids Brasil deu origem à hashtag \#primeiroassedio - promovida pelo coletivo feminista Think Olga - que produziu nas redes sociais um verdadeiro tsunami de testemunhos de assédio na infância (THINK OLGA, 2015). ${ }^{6}$ Seis meses depois, após o golpe parlamentar contra Dilma Rousseff e a ascensão de Michel Temer à presidência, a hashtag \#33contratodas conectou manifestações contra o estupro em todo o país (MELO, 2016). As mobilizações respondiam ao estupro coletivo sofrido por uma adolescente carioca $(G 1,2016){ }^{7}$

O ano de 2018 foi especialmente marcante: a 08 de março, no Brasil e em muitos outros países, acontecia a greve internacional das mulheres, cuja principal reivindicação tem sido o enfrentamento às violências e o reconhecimento da centralidade da reprodução social para a luta anticapitalista. ${ }^{8}$ Passaram-se poucos dias e as mulheres brasileiras saíram às ruas novamente, dessa vez para denunciar o assassinato da vereadora carioca Marielle Franco, "mulher negra, lésbica e da favela". Após o ato ocorrido na cidade do Rio de Janeiro durante o seu velório, manifestações se replicaram em outras cidades. Seis meses depois, presenciamos a maior mobilização de rua da recente história brasileira: milhares de mulheres ocuparam todas as capitais do Brasil e muitas cidades do mundo. Tratava-se do movimento \#elenão, em rechaço à candidatura de Jair Bolsonaro. Registros jornalísticos da época confirmaram a realização de atos em 62 cidades brasileiras e em 14 países do mundo (Bruno GÓES et al., 2018).

A trajetória dessas forças antagônicas - de reação e resistência - permite ensejar algumas considerações. Primeiro: a campanha transnacional contra os estudos de gênero demonstra como os direitos sexuais e reprodutivos têm sido atacados pela contramobilização religiosa cuja mentoria intelectual é protagonizada pela Igreja Católica. Segundo: forças seculares e de extrema-direita têm se unido a esses ataques, utilizando-os como ferramenta para o agressivo avanço neoliberal. Terceiro: a observação das dinâmicas locais permite perseguir a trajetória e entender as coalizões de forças políticas reacionárias e melhor compreender os contextos nacionais. Quarto: apesar desse quadro, as conquistas, as resistências e as alianças feministas evidenciam a força contestatória e desestabilizadora das ações protagonizadas pelas mulheres, pelos movimentos feministas e LGBT que têm enfrentado com potentes estratégias a contraofensiva religiosa, a radicalização das direitas e a restrição de direitos.

Em face dessas considerações proponho, neste artigo, descrever esses dois processos profundamente imbricados: a cruzada transnacional contra a "ideologia de gênero" e a eclosão da "primavera feminista" (Alcileide NASCIMENTO, 2018; Letícia RIBEIRO; Brena O'DWYER; Maria Luiza HEILBORN, 2018) - ou, como prefiro designar, as resistências e as alianças feministas que tiveram no \#elenão e na greve mundial das mulheres dois importantes marcos (Beatriz SANCHEZ, 2019). ${ }^{9}$ Considero-os, ambos, processos duradouros porque, embora intensificados nos últimos

\footnotetext{
${ }_{5}^{5}$ Jairo López (2018), analisando os casos de Colômbia e México, observa estratégias e repertórios similares aos que notamos no Brasil. Essa contramobilização reativa aos avanços nas conquistas de direitos sexuais e reprodutivos seria sustentada por duas formas de ativismos: o ativismo de rua e eleitoral e um ativismo institucional-legislativo (LÓPEZ, 2018, p. 163).

${ }^{6}$ Em outubro de 2015 uma garota de 11 anos estreou no programa Master Chef Kids Brasil. Sua conta no Twitter recebeu comentários sexualmente ofensivos, causando indignação nas redes sociais onde mulheres de todas as idades relataram os abusos sofridos na infância e adolescência. Em quatro dias de campanha, a hashtag foi replicada 82 mil vezes. O site organizador reuniu 3000 histórias com as quais se pode ter uma ideia dos abusos na vida das meninas brasileiras (THINK OLGA, 2015).

${ }^{7}$ Em 25/05/2016 foi publicado no Twitter o vídeo da violação de uma jovem carioca de 16 anos por mais de 30 homens.

${ }^{8} \mathrm{~A}$ greve internacional das mulheres ou a greve feminista internacional, difundida pela sigla \# $8 \mathrm{M}$, foi organizada por movimentos de mulheres e feministas em todo o mundo no dia 08 de março, quando se comemora o Dia Internacional da Mulher.

9 Beatriz Sanchez (2019) também menciona críticas ao uso da expressão "primavera feminista", considerada inapropriada por ocultar a longa trajetória de mobilizações feministas no Brasil que, apenas em 2015, receberam atenção da mídia nacional.
} 
cinco anos, estão em curso pelo menos desde o final dos anos 1990 (no caso do ativismo cristão contra os estudos de gênero) ou há muito mais tempo (no caso dos feminismos). Tendo-os abordado isoladamente em trabalhos anteriores (MELO, 2016; MELO; CANDOTTI, 2017), meu esforço neste artigo consiste em propor uma reflexão sobre os dois processos concomitantemente, dando especial atenção às condições de aparecimento e aos efeitos produzidos pelos tensionamentos e confrontos entre eles no contexto nacional.

Minha análise compreenderá, portanto, quatro linhas argumentativas. Primeiro, exponho aspectos gerais da formação genealógica do sintagma "ideologia de gênero" (JUNQUEIRA, 2017) e as condições de emergência dos ataques antigênero no Brasil, descrevendo o surgimento e a consolidação dessa categoria política acusatória no parlamento federal e em acontecimentos políticos significativos, como a aprovação do Plano Nacional de Educação (PNE), o impeachment de Dilma Rousseff e as eleições presidenciais de 2018. Na sequência, dedico-me às resistências e alianças feministas para descrever uma série de atos e mobilizações de mulheres e feministas sucedidas desde 2015 até o movimento \#elenão, passando pela greve mundial de mulheres ação política internacional aqui considerada fulcral para fortalecer as estratégias de enfrentamento aos ataques transnacionais ao gênero; mas também, e principalmente, para reposicionar os feminismos na luta anticapitalista (Cinzia ARRUZZA; Tithi BHATTACHARYA; Nancy FRASER, 2019).

Em terceiro lugar, detenho-me na trajetória da titular do Ministério da Mulher, da Família e dos Direitos Humanos para contestar as análises que classificaram como "cortinas de fumaça" (Jones MANOEL, 2018; MAIA, 2018; ESQUERDA ONLINE, 2019) as polêmicas produzidas em torno das questões de gênero e sexualidade ou de outras englobadas pelas definições de pautas "identitárias" ou "de costumes". Para alguns, as polêmicas declarações do atual presidente e de membros de seu ministério, como a ministra Damares Regina Alves, cumprem a função de deslocar a atenção pública das medidas mais importantes e em curso pelo atual governo. Assim, a estratégia da "cortina de fumaça" serviria para ludibriar a atenção e direcionar a reação dos opositores, entretendo-lhes com questões "menores", e retirar o foco de causas mais importantes, como a pauta econômica e a reforma da presidência. Para outros, a tese das "cortinas de fumaça" representa uma atualização da antiga oposição entre pautas identitárias e econômicas.

Finalmente, rememorando os ataques cometidos contra a filósofa Judith Butler $(2009 ; 2015$; 2018) durante sua última visita ao Brasil (CULT, 2017), ${ }^{10} \mathrm{em}$ novembro de 2017 , recorro a alguns de seus postulados teóricos - como performatividade, precariedade e corpos aliançados - para analisar brevemente os processos descritos.

\section{"Ideologia de gênero": gênese transnacional e coalizões locais}

Minha primeira linha de argumentação segue a genealogia da nova cruzada ou do ativismo cristão contra a "ideologia de gênero", centrando-me no caso brasileiro onde esta expressão se estabeleceu como um componente fundamental de um discurso que encontrou no Poder Legislativo um espaço privilegiado para sua institucionalização e legitimação. Por meio da apropriação desse termo, nos últimos cinco anos, grupos políticos e religiosos conseguiram banir a perspectiva de gênero dos principais marcos regulatórios da educação pública brasileira.

Tendo se estabelecido como uma "teoria religiosa de gênero" (MELO, 2016), e apesar de alusiva e antagônica aos estudos de gênero e sexualidade, a "ideologia de gênero" não é um conceito científico. Algumas autoras e autores consideram-na um "dispositivo retórico efetivo" (GARBAGNOLI, 2014, p. 251); uma "distorção semântica" (CORNEJO-VALLE; PICHARDO, 2017, p. 66); uma "categoria acusatória" (Naara LUNA, 2017, p. 34) forjada por intelectuais e teólogos católicos (O'LEARY, 1997; ALZAMORA REVOREDO, 1998; Jutta BURGGRAFF, 2004; SCALA, 2010; MÁRQUEZ; LAGE, 2016; José GUISASOLA, 2018) no final dos anos 1990 (ALZAMORA REVOREDO, 1998) "como parte de uma estratégia católica global" (KUHAR; PATERNOTTE, 2018, p. 512). No entanto, o ativismo religioso contrário aos estudos de gênero ganhou mais força e visibilidade apenas quinze anos depois, após a primeira década do século XXI. Desde então, espalhou-se por muitos países da América Latina e da Europa e tem sido utilizado para questionar e distorcer a cientificidade do conceito de gênero. As dimensões de sua difusão demonstram o alcance desse "fenômeno transnacional" organizado em muitos países por partidos políticos conservadores que utilizam a "mesma retórica da Igreja Católica" (CORNEJO-VALLE; PICHARDO, 2017, p. 33).

Como demonstram Kuhar e Paternotte (2018), a história da "ideologia de gênero" foi assaz documentada por pesquisadoras que encontraram "sua origem nos debates no Vaticano e, mais particularmente, na elaboração de uma contra estratégia após a Conferência das Nações Unidas sobre População e Desenvolvimento, em 1994, no Cairo, e a Conferência Mundial sobre as Mulheres, em 1995" (KUHAR; PATERNOTTE, 2018, p. 511 ). No Brasil, os trabalhos de Rogério Junqueira (2017), Richard Miskolci e Maximiliano Campana (2017) e Corrêa (2018) são referências importantes para

\footnotetext{
${ }^{10}$ A filósofa esteve no Brasil para ministrar conferência no seminário "Os fins da democracia", organizado pelo centro
} cultural SESC Pompéia, em São Paulo/SP. Na ocasião, a fanpage do evento recebeu ameaças (CULT, 2017). 
compreender a trajetória do termo. Por essas razões, aqui, me restrinjo ao exame das condições de emergência da "ideologia de gênero" no Brasil. Para isso, considerei, além da crescente bibliografia católica sobre o tema, uma parcela de conteúdos publicados à exaustão na internet - como imagens, vídeos e cartilhas - que me permitiu rastrear matrizes e selecionar as referências mais frequentemente citadas pelas publicações brasileiras nas redes sociais.

Na análise deste material difundido por parlamentares, lideranças religiosas e profissionais liberais, duas publicações figuram centrais: o livro The gender agenda (1997), da norte-americana Dale O'Leary, e o documento La ideología de género: sus peligros y alcance (1998), publicado pela Conferência Episcopal Peruana. O livro de O'Leary, como também sugerem outros trabalhos (JUNQUEIRA, 2018; KUHAR; PATERNOTTE, 2018), é uma das mais antigas e a principal referência de centenas de publicações brasileiras que reproduzem suas principais ideias. Nele, a autora analisa as conclusões da IV Conferência Mundial da Mulher (1995) para demonstrar como, a partir daquele evento, o termo gênero e uma agenda de políticas públicas foram progressivamente induzidos por agências internacionais e graças à atuação de ativistas e feministas "radicais". Para O'Leary, a perspectiva das mulheres - que a autora considera uma luta justa pela igualdade entre homens e mulheres observada durante os anos 1960 - teria sido suplantada pela perspectiva de gênero. Segundo a autora, o "feminismo de gênero" teria surgido na década de 1970, sob a influência das teorias de classe, constituindo-se num movimento radical e neomarxista de rejeição da família, da maternidade e de apoio à "promiscuidade".

Suas ideias, originalmente publicadas em língua inglesa, foram resumidas num documento da Conferência Episcopal Peruana, publicado em castelhano e assinado pelo bispo católico Oscar Alzamora Revoredo. Com menções superficiais ao pensamento de Judith Butler - que o religioso classificou como "ficção científica" -, o documento expõe e critica as definições de gênero, feminismo e patriarcado para denunciar a agenda de direitos sexuais e reprodutivos introduzida pela Organização das Nações Unidas (ALZAMORA REVOREDO, 1998, p. 594). Em 2003, o mesmo texto foi publicado em países europeus pelo Pontifício Conselho para a Família (2003) como parte de um léxico católico. É nesse documento da igreja católica peruana que encontramos, pela primeira vez, a menção ao sintagma "ideologia de gênero".

Nas publicações analisadas, seis estratégias discursivas se repetem à exaustão. Primeiro, a ameaça às crianças: evocar a infância, sua fragilidade e a necessidade de proteção é uma ferramenta importante para reivindicar uma educação moral baseada em valores religiosos e na autoridade familiar (SCALA, 2010). Segundo: a denúncia de uma conspiração internacional entre marxistas, comunistas, feministas e movimentos LGBT (O'LEARY, 1997; ALZAMORA REVOREDO, 1998; SCALA, 2010; MÁRQUEZ; LAJE, 2016) - um componente agregador que no Brasil permitiu a adesão de grupos seculares, como Escola Sem Partido, Movimento Brasil Livre e Revoltados On-Line. Terceiro, a reconfiguração do sexo como uma categoria normativa. A substituição das palavras "gênero", "diversidade sexual" ou "identidade de gênero" por "sexo" restitui na linguagem legal o binarismo e a heterossexualidade compulsória. Quarto, o questionamento da cientificidade dos estudos de gênero (SCALA, 2010) e a ênfase em seu caráter ideológico, ou seja, o seu poder de distorcer a realidade. Quinto, a crítica à imposição de um projeto colonial e autoritário de países ricos sobre os países mais pobres (e por meio da Organização das Nações Unidas) em prol da restauração dos termos legais forjados segundo a perspectiva cristã e ocidental (GUISASOLA, 2018). E sexto, o caráter profundamente escatológico da "ideologia de gênero", uma poderosa fábula sobre o fim do mundo que, como outras narrativas de não futuro, anuncia uma catástrofe causada pela propagação de uma "teoria pseudocientífica" que rejeita a natureza humana e promove a sua extinção (PAPA BENTO XVI, 2008).

Com efeito, apesar de criada na tradição católica, a categoria "ideologia de gênero" foi incorporada no Congresso Nacional primeiro por parlamentares evangélicos e, depois, por grupos políticos seculares. Essa coalizão representou uma estratégia importante que permitiu um intenso ativismo religioso durante o processo de aprovação do Plano Nacional de Educação (BRASIL, 2014), quando líderes católicos e evangélicos dentro e fora do parlamento se uniram para banir a perspectiva de gênero da educação. Esse confronto foi além do Congresso e nos anos seguintes alcançou os vinte e seis estados brasileiros. Em todo o país, os planos de educação aprovados excluíram expressões como gênero, sexualidade, orientação sexual e diversidade sexual.

Nesse mesmo período, observamos uma verdadeira avalanche legislativa formada pelo crescente número de propostas dirigidas à restrição dos direitos sexuais e reprodutivos. Para uma vaga ideia, em 2011 havia apenas 16 projetos sobre o assunto. Após o reconhecimento da união civil homoafetiva pelo Supremo Tribunal Federal, o número de propostas chegou a 23 em 2012 . No ano de 2015 as proposições totalizaram 125 projetos de lei dedicados, a maioria deles, a coibir a "ideologia de gênero" na educação ou impedir o reconhecimento da identidade de gênero e da equidade de gênero em políticas públicas. " Algumas dessas propostas sugeriam a criminalização

\footnotetext{
"Levantamento realizado por Rafael Gloria e Tayna Boaes, da Universidade Federal do Amazonas, no Seminário
} Violência \& Gênero no Amazonas (2016). 
de práticas educativas (PROJETO DE LEI 3235, 2015). Na área penal houve projetos para retirar a palavra gênero da lei de enfrentamento à violência doméstica e familiar contra mulheres (PROJETO DE LEI 477, 2015). Na área da saúde, uma proposta almejava revogar a Lei 12845/2013 (BRASIL, 2013) de atendimento obrigatório e integral pelo Sistema Único de Saúde (SUS) às mulheres vítimas de violência sexual (PROJETO DE LEI 6055, 2013). Além de dezenas de requerimentos para suspender a obrigatoriedade de informações sobre orientação sexual e identidade de gênero em boletins policiais e notificações de saúde.

Mais tarde, em abril de 2016, durante a votação do impedimento da presidenta Dilma Rousseff, assistimos à maioria de parlamentares favorável ao impeachment, declarando votos em prol da família e contra a suposta "ideologia de gênero". Declaração de voto significativa foi manifesta pelo Partido Humanista Solidário (PHS), representado pelo deputado federal Givaldo Carimbão. O partido se declarou contra o aborto, a "ideologia de gênero", a eutanásia e em favor do processo de destituição da presidenta. Em 2015, o mesmo congressista integrou a Comissão de Educação da Câmara Federal e atuou decisivamente pela exclusão da perspectiva de gênero nos planos de educação dos estados e municípios brasileiros (YOUTUBE, 2015).

Nas eleições presidenciais de 2018 , a campanha antigênero voltou ao centro dos debates nacionais, promovida, então, pelo candidato do PSL. Utilizando habilmente as redes sociais, sua campanha assumiu enfática e estrategicamente a cruzada contra o gênero, angariando, assim, o decisivo apoio do eleitorado evangélico (e, também, de parte do eleitorado católico). Em sua única participação nos debates eleitorais televisivos, o candidato "disparou":

Nós precisamos de um presidente honesto, que tenha Deus no coração, seja patriota e seja independente para, pelo exemplo, governar esse grande país. Um presidente que honre e respeite a família; que trate com consideração criança em sala de aula, não admitindo ideologia de gênero, impondo a Escola Sem Partido. [...] Um presidente que deixe para trás (sic) o comunismo e o socialismo (YOUTUBE, 2018a). ${ }^{12}$

Autor de polêmicas declarações consideradas misóginas (Renan RAMALHO, 2016), ${ }^{13}$ homofóbicas, racistas (Jacqueline DEISTER, 2019) ${ }^{14}$ e de apologia à tortura (Mariana DELLA BARBA; Marina WENTZEL, 2016; Raquel MORAIS, 2015), ${ }^{15}$ a candidatura do criador do kit gay (CONSELHO NACIONAL DE COMBATE À DISCRIMINAÇÃO, 2004; CÂMARA DOS DEPUTADOS, 2011 ) $^{16}$ desencadeou a reação de milhares de mulheres que organizaram o movimento \#elenão. Suas declarações são representativas do modo como grupos políticos e religiosos conseguiram disseminar, no Brasil, a oposição à "ideologia de gênero", a ponto de esta dividir espaço na agenda pública e eleitoral com temas como a segurança pública e a corrupção. Não por acaso, sua menção aos termos "ideologia de gênero" e "doutrinação ideológica" nos remete à mesma abordagem discursiva observada nas reformas educacionais no Brasil e nas publicações cristãs que denunciam uma "conspiração internacional". Além disso, o excerto é revelador da poderosa aliança nacional entre grupos políticos religiosos - representados principalmente pela Frente Parlamentar Evangélica do Congresso Nacional - e movimentos de extrema-direita.

\section{A "primavera feminista": resistências e alianças}

E porque há muitos caminhos possíveis, não temos um mapa, mas peças de um puzzle com as quais compomos. Peças recortadas e coladas que vão se unindo em uma imagem possível. Porque, também, o que propomos é uma collagem: de ideias, vidas, experiências e propostas (AQUÍ ESTAMOS, 2019, p. 11).

Foi precisamente para rejeitar essa candidatura que o movimento "Mulheres contra 0 Fascismo" ou "Mulheres contra Bolsonaro" se formou e difundiu o lema-hashtag \#elenão. Na rede

12 Transmissão televisiva de 09/08/2018.

${ }^{13} \mathrm{Em} \mathrm{2014}$, reportando-se à deputada federal Maria do Rosário (PT/RS), o deputado havia afirmado: "Eu não sou estuprador, mas, se fosse, não iria estuprar, porque não merece". Em 2019, foi condenado em ação de danos morais promovido pela ofendida (RAMALHO, 2016).

${ }_{14} \mathrm{O}$ atual presidente foi também condenado por declarações homofóbicas e racistas manifestas em programa televisivo no ano de 2011 (DEISTER, 2019).

${ }^{15}$ Em abril de 2016, na sessão plenária da Câmara Federal em que se aprovou o processo de impeachment da expresidenta Dilma Rousseff, o parlamentar declarou: "Pela memória do coronel Carlos Alberto Brilhante Ustra, o pavor de Dilma Rousseff, pelo exército de Caxias, pelas Forças Armadas, pelo Brasil acima de tudo e por Deus acima de todos, o meu voto é sim" (DELLA BARBA; WENTZEL, 2016); Ustra foi chefe do DOI-CODI - órgão de repressão política durante o regime militar - e responsabilizado pela justiça brasileira por torturar presos políiticos (MORAIS, 2015).

${ }^{16}$ Em fevereiro de 2011 , a expressão "kit gay" foi empregada pela primeira vez para designar, pejorativamente, 0 material didático Escola Sem Homofobia, produzido pelo Ministério da Educação como parte do Programa Brasil sem Homofobia (CONSELHO NACIONAL DE COMBATE À DISCRIMINAÇÃO, 2004). Tratava-se de um pronunciamento do então candidato à presidência da Câmara Federal, em 01/02/201 1: "Jovens Parlamentares, este ano escolas públicas de primeiro grau estão distribuindo um kit gay de estímulo ao homossexualismo e à promiscuidade, com a participação desta Casa. [...] Cabe à Presidência da Casa trazer este tema para cá - votarmos essa questão - e não deixar que o Executivo legisle e crie currículo de assunto tão importante junto à garotada do primeiro grau" (CÂMARA DOS DEPUTADOS, 2011). 
social Facebook, o movimento engajou algo em torno de 3 milhões de participantes no grupo (CORREIO BRAZILIENSE, 2018) ${ }^{17}$ e, em 29 de setembro de 2018, produziu uma das maiores manifestações da história recente do Brasil. Em todos os estados brasileiros, milhões de mulheres gritaram: "Ele não!", "Ele nunca!", "Ele nem com nojo!”. Naquele dia, centenas de mensagens, áudios, vídeos e imagens circularam nas redes sociais, visibilizando a união de mulheres muito diferentes e diversas, de várias partes do país (Belém, Manaus, Rio de Janeiro, São Paulo, Maceió, Itacoatiara, Juiz de Fora) e do mundo (Lisboa, Madri, México, Londres, Paris). Inclusive, muitas que jamais se haviam declarado ou reivindicado feministas.

Após a grande marcha, e apesar disso, o candidato saiu vitorioso, razão pela qual algumas análises concluíram que as manifestações teriam causado um efeito negativo e motivado a sua eleição. Reaparecia, então, a famosa teoria do backlash questionada meses depois das eleições presidenciais em um artigo jornalístico de Debora Diniz e Giselle Carino (2019), no qual as autoras recusavam com sagacidade o jogo de causa-consequência, uma dentre tantas atualizações da culpabilização feminina. ${ }^{18}$

Para muitos, o movimento que emergiu nas redes sociais foi repentino e efêmero, mas se observarmos a trajetória das mobilizações de mulheres, feministas e LGBT nos últimos anos (mas não apenas), notaremos a persistente e crescente onda de mobilizações, resistências e alianças, denominadas pela mídia nacional de "primavera feminista" em 2015-por ocasião do movimento \#primeiroassedio - e de "junho lilás" em 2016. Assim, será possível reconhecer não apenas a potência das/nas redes sociais como um prolongado processo de mobilização, mas também uma atuação capilar e cotidiana, direcionada sempre para as ruas e ocupando-as em movimentos disruptivos sempre e quando sua existência e direitos são ameaçados.

Em 2016, um vídeo no Twitter mostrou o estupro de uma adolescente carioca. Entre os comentários que reagiram à postagem, muitos mostraram admiração e aprovação àqueles que orgulhosamente exibiam sua participação no "túnel". Um deles explicou: "Eles fizeram um túnel na garota". A expressão aludia aos vários homens que penetraram a jovem: mais de trinta, segundo os comentários de seus divulgadores. Rapidamente, a hashtag \#33contratodas foi divulgada e centenas de perfis foram emoldurados com a frase "Eu sou contra a cultura do estupro". O ativismo virtual superou as redes sociais e em 21 capitais brasileiras foram organizados eventos "pelo fim da cultura do estupro". Em São Paulo, na noite do dia 01 de junho, de mãos unidas, mães com suas filhas e filhos nos braços formaram um cordão humano que liderou a marcha. Nos cartazes empunhados, frases como "Fora Temer", "Machismo mata, Feminismo liberta", "Nenhuma mulher merece ser estuprada" (ESTADÃO, 2016).

As mobilizações conhecidas como "junho lilás" fortaleceram as manifestações de oposição ao governo interino de Michel Temer e, naquela noite, muitas bandeiras diferentes foram agitadas ao som do coro polifônico: "Pelo fim da cultura do estupro", "Somos todos Dilma", "Fascistas não passarão". Note-se que aqui outra coalizão foi desenhada: uma coalizão de mulheres contra o estupro; pela vida das mulheres, da democracia e contra a reemergência dos conservadorismos, dos extremismos de direita e do avanço de uma série de reformas que, desde então, acompanhamos quase que diariamente. Não se tratava, portanto, de uma questão atinente apenas às mulheres, tampouco de reivindicar somente o direito à "liberdade sexual", mas de conectar essa a outras lutas, sem hierarquizá-las.

Essa coalizão, a visibilidade desses corpos aliançados nas redes sociais e nas ruas, passaram a fazer parte da dinâmica dos enfrentamentos políticos vivenciados no país desde então. Em março de 2018, durante a mobilização do dia internacional das mulheres, as articulações feministas brasileiras encontraram suporte e projeção internacional com a greve mundial de cuidados, reposicionando a pauta de reivindicações feministas como central na luta anticapitalista e reivindicando o reconhecimento da centralidade da reprodução social para a produção, tal como reafirmou Silvia Federici em sua última visita ao Brasil (Bruna LARA, 2019).

Naquele mesmo mês, seis dias depois do \#8M, a denúncia do racismo se conectaria de forma incisiva e dramática às performatividades feministas brasileiras, com o assassinato da vereadora Marielle Franco (PSOL). Em 14 março de 2018, Marielle foi alvejada: 13 tiros atingiram o seu carro e 04 deles a mataram. Horas antes, ela esteve na Casa das Pretas, no evento "Jovens negras movendo as estruturas". Após a sua queda, milhares de mulheres, enlutadas, levantaramse e ocuparam as ruas manchadas de sangue. Na cidade de São Paulo, 30 dias depois do assassinato, centenas de mulheres ocuparam mais uma vez o vão do Museu de Arte de São Paulo (MASP) e caminharam pela Av. Paulista. Nossos corpos, aliançados, denunciavam a impunidade,

\footnotetext{
${ }^{17}$ O grupo do Facebook "Mulheres unidas contra Bolsonaro" alcançou, em meados de setembro de 2018, cerca de 2,5 milhões de participantes. Após ataques cibernéticos e ameaças contra as administradoras do grupo, as hashtags \#mulherescontrabolsonaro e \#elenão lideraram o trending topics do Twitter em 16/09/2018.

${ }^{18}$ Nas palavras das autoras: "Não há backlash provocado pelo feminismo, mas o permanente uso do poder para manter o status quo de coerção reprodutiva às meninas e mulheres. Backlash nada mais é do que 'culpar a vítima' por não cumprir com o destino traçado pelo patriarcado" (DINIZ; CARINO, 2019). Como afirmei antes, esse esforço de manutenção do status quo é analisado por López como contramobilização reativa à conquista de direitos (cf. nota 06 ).
} 
o machismo e o genocídio negro. Entre cantos, declarações emocionadas e toques de tambores, escrevemos nas ruas e no asfalto novas marcas de nossa existência violentamente repelida. Um ano depois, dois policiais foram presos pelo crime, de evidente motivação política e mandatário ainda desconhecido.

Como demonstram tais mobilizações, não apenas os ataques antigênero e a contramobilização são transnacionais, mas as lutas das mulheres e dos movimentos feministas e LGBT também atravessaram as fronteiras dos Estados-Nação e, ao mesmo tempo, se produziram capilarmente com profundas raízes fortes cultivadas no trabalho ordinário, no cotidiano. Por outro lado, arraigadas nos contextos nacionais, essas lutas mantêm laços longínquos que evidenciam a internacionalização do enfrentamento à violência, da reivindicação por isonomia salarial, pelo reconhecimento da centralidade da reprodução social, seja para a luta anticapitalista (como reivindica o feminismo para os $99 \%^{19}$ ), seja para a proposição de outros mundos, pois:

As demandas das mulheres - metade da população - supõem necessariamente um questionamento da ordem das coisas. O feminismo é transformador e propõe uma alternativa real ao avanço do neoliberalismo e da direita porque abarca tudo. É uma perspectiva sobre o mundo que impugna desde as bases do nosso sistema - a distinção entre trabalho produtivo e reprodutivo, por exemplo; ou um contrato social que não pode entender-se sem sua parte de contrato sexual - para propor outro modo de pensar e de fazer as coisas, outro modo possível de habitar - e, portanto, de construir o mundo (AQUÍ ESTAMOS, 2019, p. 06).

\section{Sobre golabeiras e cortinas de fumaça}

Em janeiro de 2019 tomava posse como ministra da Mulher, da Família e dos Direitos Humanos, a advogada paranaense Damares Regina Alves. Pastora da Igreja do Evangelho Quadrangular, desempenhou por mais de duas décadas o papel de assessora parlamentar para a Frente Parlamentar Evangélica (antiga Bancada Evangélica) do Congresso Nacional. Sua atuação foi determinante para alavancar propostas legislativas - como a lei de criminalização do "infanticídio indígena" (PL 1057/2007) e obstaculizar outras, como a lei de atenção integral às vítimas de violência sexual no Sistema Único de Saúde (Lei 1258/2013) (A campanha "Não quero sangue inocente em minhas mãos!" buscava impedir a sanção do PLC 03/2013, transformado na lei 12845/2013 que garantiu "atendimento obrigatório e integral de pessoas em situação de violência sexual" [YOUTUBE, 2013]). ${ }^{20}$

Segundo dados do Congresso Nacional, foi assessora de nove parlamentares, todos evangélicos: primeiro, de seu tio, o deputado federal Josue Bengtson (PTB/PA); em seguida, do Pastor Reinaldo (PTB/RS), da Igreja do Evangelho Quadrangular; João Campos (PSDB/GO), pastor da Assembleia de Deus em Goiânia (GO); Henrique Afonso (PV/AC), da lgreja Presbiteriana; Roberto de Lucena (PODE/SP), da lgreja O Brasil para Cristo (OBPC) e Arolde de Oliveira (DEM/RJ), da Primeira Igreja Batista de Niterói. Seus últimos cargos antes do ministério foram como assessora do exsenador Magno Malta (PR/ES) e consultora jurídica da Frente Parlamentar Evangélica e da Frente Parlamentar pela Família e Apoio à Vida (Marcelo AULER, 2018). Não por acaso, ao ser indicada para o ministério, uma centena de entidades religiosas e seculares apoiou sua nomeação:

No contexto dos acontecimentos nacionais e internacionais do ano de 2018, Damares Alves representa a proteção da vida humana, da concepção da morte natural, a garantia dos direitos humanos fundamentais, a defesa da dignidade humana, a reconstrução dos direitos humanos, o espírito de renascimento da esperança e da fraternidade que caracterizam a sociedade que desejamos ter (Jônatas LIMA, 2018).

Nos anos 1980, atuou em movimentos sociais, como o Movimento Nacional de Meninos e Meninas de Rua. Diz-se sobre ela que, além de receber em sua própria casa muitos dos meninos e meninas que acompanhava, por vezes, dormiu nas ruas com eles. Filha de pastor da Igreja do Evangelho Quadrangular, se formou advogada e tornou-se também pastora. Além da prolongada e intensa atuação nos bastidores do parlamento federal - o que lhe conferiu prestígio entre parlamentares e lideranças religiosas -, a sua nomeação como ministra representou a aliança entre a presidência e o eleitorado evangélico que a elegeu (TEIXEIRA, 2019, In Marina ROSSI, 2019). Com efeito, sua atuação no governo está muito distante de ser uma participação irrisória, seja pelo papel que desempenha na aliança entre a presidência e o evangelismo; seja pela consolidada trajetória política construída por uma mulher cujas declarações - pretéritas e atuais - são frequentemente alvo de chacotas.

Uma de suas tão polêmicas declarações foi proferida ainda nos primeiros dias do novo cargo, quando reunida com assessores e assessoras a portas fechadas: "Uma nova era começa no Brasil: menino veste azul e menina veste rosa!". A frase foi repetida em coro e euforicamente -

${ }^{19} \mathrm{Em} 2019$, como parte das ações da Greve Internacional das Mulheres, no \#8M, foi lançado, simultaneamente em 08 países, o Manifesto Feminismo para os 99\% (ARRUZZA, BHATTACHARYA; FRASER, 2019).

${ }^{20}$ Para informações sobre as propostas legislativas para invalidar esta lei, cf. nota 15. 
entre gritos de "aleluia" - pelas pessoas presentes naquela sala. Ao redor da ministra, entre corpos majoritariamente masculinos e trajando ternos, víamos a bandeira de Israel e a do Brasil sob os ombros de dois dos participantes da comemoração (YOUTUBE, 2019).

Antes mesmo de ser formalmente instituída no cargo, a ministra "virou assunto" nas redes sociais que reproduziam (e ridicularizavam) à exaustão um vídeo em que a pastora testemunhava um abuso sexual sofrido na infância:

Eu quis me matar. [...] Eu peguei uma substância, entenderam? E eu ia tomar aquela substância. Eu vou contar uma coisa para vocês: a casa do meu pai era uma casa pastoral e ficava no fundo da igreja e do lado da casa do meu pai tinha um pé de goiaba, e é naquele pé de goiaba que eu subia e chorava. E no dia que eu estava com o veneno em cima do pé de goiaba aconteceu algo extraordinário. [...] Eu estava em cima do pé de goiaba com veneno na mão e quando eu ia comer o veneno aconteceu algo extraordinário. Eu vi Jesus se aproximando do pé de goiaba. Eu tive uma revelação extraordinária! [...] E quando eu vi Jesus, irmãos, eu esqueci o veneno. Olha como Deus é criativo: eu esqueci o veneno, eu não tomei o veneno. E daqui a pouco Jesus Cristo começou a se aproximar do pé de goiaba e ele olhava para mim, e ele era tão lindo. Ele tinha uma roupa comprida, uma barba comprida, aquela visão que a criança tem Jesus. Mas Jesus não se aproximou só do pé de goiaba. Sabe o que aconteceu? Jesus Cristo começou a subir no pé de goiaba. [...] E lá naquele galho no pé de goiaba, Jesus Cristo meu deu o abraço que a igreja não deu, Jesus Cristo me deu o abraço que a mamãe e o papai não me deram. E naquele pé de goiaba acontece um milagre: a menininha que Satanás quis esmagar aos seis anos de idade foi transformada e essa menininha hoje está lá no Senado Federal escrevendo leis para salvar crianças do Brasil. Essa menininha está andando pelo Brasil dizendo: Igreja, cuida! (YOUTUBE, 2018b).

De sua breve biografia, apreendemos uma extensa trajetória política dentro e fora do parlamento que inclui cargos no executivo (Damares foi secretária de assistência social em São Carlos/SP) e pregações em púlpitos de igrejas por todo o país, nas quais o testemunho pessoal não é simplesmente uma ferramenta retórica, mas evoca a autoridade da experiência para engajarse na salvação das crianças e instar seus expectadores à batalha cristã para ocupar o Estado.

Seu discurso de sofrimento, mas também de superação e empoderamento, é evidenciado em um excerto importantíssimo de sua pregação, eclipsado por leituras superficiais que gravitam ao redor de goiabeiras: "essa menininha hoje está lá no Senado Federal escrevendo leis para salvar crianças do Brasil”. Trata-se de uma sentença simples, mas poderosa e que nos remete aos argumentos de Jacqueline Teixeira (2019) sobre o empoderamento das mulheres e a experiência religiosa no evangelismo brasileiro. Trata-se de uma narrativa de superação que expõe a fragilidade e a violação da infância, mas também a resiliência e um protagonismo transformador não apenas de uma trajetória pessoal, mas do mundo secular, "salvando as crianças do Brasil".

Subestimar a trajetória de Damares e atribuir-lhe a função de marionete do governo na produção de "cortinas de fumaça" menospreza a sua importância na coalizão conservadora que tornou possível a eleição do atual presidente e reproduz um esquema hierárquico que inferioriza a atuação política das mulheres e de suas demandas, negando-lhes protagonismo. E isso permite acessar outra dimensão da tese das "cortinas de fumaça", aquela que considera não apenas os sujeitos emissores das polêmicas, mas também o conteúdo de suas mensagens: as "pautas identitárias" ou de "costumes". Noutras palavras, as questões de gênero e sexualidade incisivamente confrontadas pelos ataques transnacionais ao gênero e reivindicadas pelas resistências e alianças feministas.

Em uma argumentação convincente e competente, Piero Leirner (2018) tem insistido que o modus operandi do atual governo está baseado em táticas de guerra extraídas de manuais militares. As estratégias seriam, por exemplo, o disparo de "bombas semióticas", declarações polêmicas e ataques generalizados produzidos no intuito de atordoar e imobilizar os inimigos, dispersando-os. Como vimos, desde as eleições presidenciais de 2018 , o volume de polêmicas e ataques produzidos quase que diariamente logra o efeito desejado de confundir e dispersar a reação da oposição ao governo.

No entanto, acredito que se equivoca quem se apropria dessa análise para concluir que os ataques ao gênero institucionalizados na atual gestão federal constituiriam tão somente um estratagema para desviar as atenções de assuntos mais importantes ou ameaças mais graves. Essas conclusões são geralmente baseadas na oposição entre minorias versus economia. E, embora componham um certo repertório de oposição ou esquerda, também fazem parte dos discursos daqueles que participam do governo. Esse foi o caso da declaração do líder da Frente Parlamentar Evangélica no Congresso Nacional, o deputado federal Silas Câmara (PRB/AM), pastor da lgreja Assembleia de Deus, ao enfatizar, em março de 2019, a necessidade de aprovação da Reforma da Previdência (a Proposta de Emenda à Constituição n 6, de 2019 - Reforma da Previdência, foi aprovada no Senado Federal no dia 01/10/2019 [SENADO FEDERAL, 2019]).

As "cortinas de fumaça" revelam, na verdade, uma posição política. Uma adesão sólida e estável ao combate da "ideologia de gênero", estratégia que, no contexto brasileiro, precisa ser 
entendida como central para a emergência do atual presidente, cuja primeira grande projeção, convém recordar, se deu em 2011 , com a difusão do falacioso kit gay (cf. nota 21). E Damares Alves corporifica exemplarmente esse projeto político.

As supostas "pautas comportamentais" incidem diretamente na política externa (relembremos as posições do país na Organização das Nações Unidas - ONU e os episódios de Brigitte Macron [Ansa, 2019] ${ }^{21}$ e Michelle Bachelet [G1, 2019] ${ }^{22}$ ); na economia (como revelam os impactos da avassaladora reforma da previdência); e na educação (como evidenciaram as disputas pelos planos de educação). Essas questões não são, de modo algum, particulares ou setoriais. A contraposição minorias/economia ignora a apropriação neoliberal das normatividades de gênero e o entrecruzamento entre desigualdades de gênero, de raça/etnia, e de classe. Afinal, as opressões de gênero, raça/etnia e classe são estruturantes e operam conjuntamente na produção e ampliação da precariedade. Podemos, contudo, empregar a metáfora a nosso favor. Pois, se onde há fumaça, há fogo, então as resistências feministas são o fogo que a fumaça conservadora tenta, sem sucesso, ocultar.

\section{O que a bruxa e a fogueira nos ensinam?}

Quando os corpos se reúnem na rua, na praça ou em outras formas de espaço público (inclusive virtuais), eles exercem um direito plural e performativo de aparecer, um direito que afirma e estabelece o corpo em meio ao campo político que, em sua função expressiva e significativa, transmite uma exigência corpórea de um conjunto mais suportável de condições econômicas, sociais e políticas, não mais afetadas pelas formas induzidas de condição precária (Judith BUTLER, 2018, p. 17).

No final de 2017, Judith Butler esteve no Brasil (MISKOLCl; Pedro Paulo PEREIRA, 2018). ${ }^{23} \mathrm{Em}$ frente ao centro cultural Sesc Pompeia (São Paulo/SP), onde a filósofa ministraria uma conferência, dezenas de manifestantes religiosos dividiram espaço com militantes feministas e LGBT que desejavam saudar e apoiar a filósofa. Com cruzes e bíblias em suas mãos, os adversários de Butler trouxeram uma boneca da "bruxa" que foi incendiada no protesto. Citada nos documentos cristãos, ameaçada nas redes sociais, perseguida no aeroporto de Congonhas/São Paulo (Nelson GOBBI, 2017) a filósofa referência mundial dos estudos Queer tornou-se a inimiga número um dos ataques internacionais antigênero.

Ironicamente, é precisamente em seus trabalhos (BUTLER, 2009; 2015; 2018) que tenho encontrado caminhos de análise muito férteis para entender os dois processos antagônicos descritos nas seções anteriores deste artigo. Como afirmado em trabalhos anteriores (MELO; CANDOITI, 2017), os enquadramentos produzidos por essa "teoria religiosa do gênero" ampliam a exposição dos corpos precarizados, reivindicam normatividades de gênero hegemônicas e ameaçam efetivamente as condições de visibilidade e sobrevivência.

Essas poderosas discursividades não apenas disputam espaço com os estudos de gênero pela legitimidade de regular e produzir "o gênero", mas, efetivamente, impedem a vida dos corpos mais precarizados e vulneráveis. Por exemplo, figuram como materialização da morte e da precariedade às proposições legislativas que almejavam impedir a contabilização das mortes de pessoas não heterossexuais em relatórios policiais e de saúde pública; ou os projetos e campanhas contrários à atenção integral de meninas e mulheres vítimas de violência sexual.

Voltando ao caso colombiano, temos outro flagrante da seletividade das vidas passíveis de luto (BUTLER, 2015). Para Camila Muelle (2017), a campanha católica pelo "No" ao referendo evidencia como a existência do outro pode chegar a ser percebida como uma ameaça às vidas "legítimas" (MUELLE, 2017, p. 174), tal como exposto nos teor do manifesto em que organizações cristãs não apenas requeriam o reconhecimento das organizações religiosas, mas a supressão do reconhecimento da vulnerabilidade de pessoas LGBT no conflito. Uma operação exemplar das vidas que merecem ser vividas, das vidas dignas de luto.

Por outro lado, a insistente e persistente atuação política de mulheres, feministas e LGBT, nas redes sociais e nas ruas, demonstra formas de performatividade corporificada e plural de resistência, aparição, solidariedade e aliança (BUTLER, 2018, p. 14). Nesse sentido, quando as mulheres negras ocuparam as ruas e praças de todo o país para reivindicar o luto e a apuração do assassinato de Marielle Franco, experimentavam outras formas de existência e resistência visibilizadas pela trajetória daquela "mulher, negra, mãe, lésbica e da periferia" que, parafraseando Angela Davis (YOUTUBE,

\footnotetext{
${ }^{21}$ Em meio ao incidente diplomático entre Brasil e França por ocasião dos incêndios na Amazônia, em agosto de 2019, o presidente brasileiro comentou uma publicação ofensiva à primeira dama francesa, Brigitte Macron (Ansa, 2019).

22 Em setembro de 2019, respondendo às críticas da comissária da ONU, Michelle Bachelet, sobre a democracia brasileira, o presidente brasileiro elogiou a ação militar que, sob o governo ditatorial de Augusto Pinochet, assassinou centenas de opositores políticos no Chile, dentre eles, o pai da comissária, Alberto Bachelet (G1, 2019).

${ }^{23}$ A este respeito, consultar Miskolci e Pereira (2018) e todo o volume 53 (2018) do Cadernos Pagu, em que pesquisadores/as analisam detidamente esse episódio da cruzada brasileira antigênero.
} 
2017), ${ }^{24}$ havia movido as estruturas do machismo, do racismo, da heteronormatividade e das desigualdades de classe.

A ocupação das ruas e praças por aqueles corpos aliançados constituiu-se - tomando de empréstimo, mais uma vez, o vocabulário butleriano (BUTLER, 2018) -, no momento mesmo de sua reunião, o suporte para e o espaço político de aparição daqueles corpos precarizados e privados do luto. Tratava-se, pois, da constituição de um espaço liminar, um espaço entre, no qual a presença nas ruas produzia um espaço de aparição; denunciava a precarização; subvertia o luto; e materializava a presença de Marielle que ressurgia em milhares de outras mulheres justamente por compartilharem da mesma precariedade que torna as suas vidas mais vulneráveis que outras.

As formas de suporte, ocupação e produção de espaços de aparição pública, inclusive nas redes sociais, subvertem a oposição público-privado e ratificam a antiga máxima feminista "o pessoal é político", ampliando-a para "o doméstico é público". Assim, recusam continuamente a impossibilidade da ação política no convívio doméstico. Os testemunhos virtuais de assédio são um exemplo potente dessa forma de aparição e ação política, também reveladora do modo como as redes sociais podem se configurar como espaço político a ser disputado.

Ora, pelo mesmo agente sociotécnico em que se performaram fake news e que se propagou o sintagma "ideologia de gênero", acontecimentos confinados à "vida privada" têm sido amplamente publicados por meio de uma sucessão interminável de hashtags empregadas por milhares de mulheres para revelar segredos de violações e assédios protegidos pelo sigilo familiar, das relações de trabalho e acadêmicas. Afinal, como argumenta Butler (2018, p. 91), a "esfera pública" é construída por exclusões e negações que em alguma medida asseguram a invisibilidade dessas violações, impedindo a sua divulgação.

Nesses espaços, os corpos aliançam-se de uma forma que não lhes seria permitido de outra maneira (BUTLER, 2018, p. 14). Assim, as ferramentas virtuais não se configuraram apenas como um meio, um instrumento pelo qual essas mulheres conseguiram ocupar as ruas, mas espaços em si mesmos, objetos de agência, de aparição e de aliança baseada no compartilhamento da vulnerabilidade. Por intermédio dessa plataforma, por exemplo, localizaram a jovem carioca violada por 33 homens. Foi também assim que o \#meuprimeiroassedio conseguiu reunir dados que permitiram traçar um primeiro diagnóstico brasileiro sobre o assédio sexual na infância. Com efeito, as redes sociais podem também se configurar como plataforma e apoio - no mesmo sentido que Butler (2018, p. 81) atribuiu a "suporte" - para que ação política aconteça e para que esses corpos sejam reconhecidos. E essas alianças, poderosas, oferecem suporte político, afetivo e efetivo de aparição, reconhecimento e compartilhamento de nossa precariedade, mas também, e justamente por isso, de solidariedade e apoio.

Em março de 2019, durante a greve mundial de cuidados, em Madri/Espanha, eu participava das atividades do \#8M e pude experimentar novamente o que havia sentido em São Paulo, ao rememorarmos o primeiro mês do assassinato de Marielle Franco. A capital europeia que se pretende a "tumba do machismo" vestiu-se de lilás e meio milhão de mulheres apareceram, ocupando suas avenidas mais famosas. Dentre os incontáveis cartazes e frases de efeito, se escutavam os gritos estridentes de um grupo de adolescentes: "Tranquila, hermana, aqui está tu manada". A frase aludia ao estupro coletivo de uma jovem em Pamplona (Espanha) no ano de 2016, conhecido como La Manada (Reyes RINCÓN, 2019). Estávamos de fato tranquilas, podíamos finalmente caminhar pelas ruas sem medo. E experimentar outras vidas possíveis, e finalmente chorar o nosso luto. Lá, como aqui, no Brasil, reconhecíamo-nos em nossas diferenças, medos e silêncios. E não estávamos sós.

Podem nos queimar, mas não somos fumaça, somos fogo!

\section{Referências}

ACIPRENSA. "Colombia: Miles piden sacar ideología de género del acuerdo de paz con las FARC". Aciprensa, 2016. Disponível em https://www.aciprensa.com/. Acesso em 20/10/2019.

ALZAMORA REVOREDO, Oscar. "La ideología de género: sus peligros y alcances". In: Consejo Pontificio Para La Familia. Lexicón de términos ambiguos y discutidos sobre familia, vida y cuestiones éticas. Madrid: Palabra, 1998.

ANSA. "Bolsonaro faz piada sobre esposa de Macron". IstoÉ, 26/08/2019. Disponível em https://n9.cl/ obrx. Acesso em 19/10/2019.

AQUÍ ESTAMOS. Puzzle de un momento feminista. Madrid: AKAL, 2019.

ARRUZZA, Cinzia; BHATTACHARYA, Tithi; FRASER, Nancy. Feminismo para os $99 \%$ : um manifesto. São Paulo: Boitempo, 2019.

${ }^{24}$ Alusão ao discurso de Angela Davis em conferência na Escola de Pensamento Feminista Negro, em 17/07/2017, na cidade de Cachoeira-BA. Na ocasião, a feminista declarou: "quando as mulheres negras se movem, toda a estrutura política e social se movimenta na sociedade". 
AULER, Marcelo. "Damares, futura ministra, como pastora voou com cotas parlamentares". Marcelo Auler Repórter, 22/12/2018. Disponível em https://cutt.ly/ehaV9AU. Acesso em 03/09/2019.

BALIEIRO, Fernando de Figueiredo. "Não se meta com meus filhos: A construção do pânico moral da criança sob ameaça”. Cadernos Pagu, n. 53, E185306, 2018.

BORGES, Rafaela Oliveira; BORGES, Zulmira Newlands. "Pânico moral e ideologia de gênero articulados na supressão de diretrizes sobre questões de gênero e sexualidade nas escolas". Revista Brasileira de Educação, n. 23, E230039, 2018.

BRASIL. Lei $n .12 .845$, de $1^{\circ}$ de agosto de 2013. Dispõe sobre o atendimento obrigatório e integral de pessoas em situação de violência sexual. Brasília, 2013. Disponível em https://n9.cl/x0s5.

BRASIL. Lei n. 13.005, de 25 de junho de 2014. Aprova o Plano Nacional de Educação - PNE e dá outras providências. Brasília, 2014. Disponível em https://n9.cl/4vm1.

BURGGRAFF, Jutta. ¿Qué quiere decir género? En torno a un nuevo modo de hablar. San Jose: Promessa, 2004.

BUTLER, Judith. Corpos em aliança e a política das ruas: notas para uma teoria performativa de assembleia. Rio de Janeiro: Civilização Brasileira, 2018.

BUTLER, Judith. Cuerpos que importan: sobre los límites materiales y discursivos del 'sexo'. Buenos Aires: Paidós, 2009.

BUTLER, Judith. Quadros de guerra: quando a vida é passível de luto. Rio de Janeiro: Civilização Brasileira, 2015.

CALCAGNO, Luis; CARDIM, Maria Eduarda. "Pautas de costumes se sobrepõem à economia no governo Bolsonaro". Correio Braziliense, 2019. Disponível em https://n9.cl/fl1z. Acesso em 18/10/ 2019.

CÂMARA DOS DEPUTADOS. Sessão 002.1.54.P. Orador: Jair Bolsonaro. Brasília: Câmara dos Deputados, 01/02/2011. Disponível em https://cutt.ly/7haC8dS.

CONSELHO NACIONAL DE COMBATE À DISCRIMINAÇÃO. Brasil Sem Homofobia: Programa de combate à violência e à discriminação contra GLTB e promoção da cidadania homossexual. Brasília: Ministério da Saúde, 2004. Disponível em https://cutt.ly/ihaBgKt. Acesso em 03/09/2019.

CORNEJO-VALLE, Mónica; PICHARDO, José Ignacio. “La 'ideología de género' frente a los derechos sexuales y reproductivos en el escenario español”. Cadernos Pagu, n. 50, E1 75009, 2017.

CORRÊA, Sonia. "A 'política do gênero': um comentário genealógico”. Cadernos Pagu, n. 53, E185301, 2018.

CORREIO BRAZILIENSE. "Após ser hackeada, página 'Mulheres Unidas contra Bolsonaro' volta ao ar". Correio Braziliense, 16/09/2018. Disponível em https://cutt.ly/QhaVeXN. Acesso em 16/08/2019.

CULT. "Sesc Pompeia sofre ataques por sediar evento com Judith Butler". Cult, 27/10/201 7. Disponível em https://n9.cl/siu5.

DELLA BARBA, Mariana; WENTZEL, Marina. "Discurso de Bolsonaro deixa ativistas 'estarrecidos' e leva OAB a pedir sua cassação". BBC News Brasil, 19/04/2016. Disponível em https://n9.cl/yli9. Acesso em 16/08/2019.

DEISTER, Jacqueline. "Bolsonaro é condenado a pagar R\$150 mil por declarações racistas e homofóbicas". Brasil de Fato, Rio de Janeiro, 14/05/2019. Disponível em https://cutt.ly/ZhaVGHP. Acesso em 16/08/2019.

DINIZ, Debora; CARINO, Giselle. “Não há ‘backlash' provocado pelo feminismo”. El País, 2019. Disponível em https://n9.cl/5v62. Acesso em 20/10/2019.

ESQUERDA ONLINE. "Cortina de fumaça: uma polêmica com o economicismo". Esquerda Online, 2019. Disponível em https://n9.cl/ibdrt. Acesso em 18/10/2019.

ESTADÃO. A sociedade naturaliza a cultura do estupro. Estadão, 28/05/2016. Disponível em https:/ /n9.cl/1tve9. 
FERNANDES, Vitor. "A pauta identitária e a divisão da esquerda". Jornal GGN, 2018. Disponível em https://n9.cl/oku9n. Acesso em 18/10/2019.

FERNANDÉZ, Marta Cabezas. "Silencing feminism? The imagined nation of the Spanish far-right and its challenge to gender violence policy". CONFERENCIA INTERNACIONAL IFJP-FLACSO FEMINISMOSY CONSERVADURISMOS EN AMÉRICA LATINA. Anales... Ciudad de México, 2019.

G1. "Declarações de Bolsonaro em resposta a Michelle Bachelet geram críticas". G1, 04/09/2019. Disponível em https://cutt.ly/zhaVohe. Acesso em 19/10/2019.

G1. "Vítima de estupro coletivo no Rio conta que acordou dopada e nua". G1, 27/05/2016. Disponível em https://cutt.ly/HhaBcRv.

GARBAGNOLI, Sara; PREARO, Massimo. La croisade anti-genre: du Vatican aux manif pour tous. Paris: Petit Encyclopédie Critique, 2017.

GARBAGNOLI, Sara. "'Lideologia del genere': l'irresistibile ascesa di un'invenzione retorica vaticana contro la denaturalizzazione dell'ordine sessuale". About Gender Rivista Internazionale di Studi di Genere, v. 3, n. 6, 2014.

GÓES, Bruno; HERDY, Thiago; CAMPOREZ, Patrik. "Manifestantes fazem ato contra Bolsonaro em pelo menos 62 cidades brasileiras". O Globo, 2018. Disponível em https://n9.cl/5s3h. Acesso em 20/10/ 2019.

GOBBI, Nelson. "Escritora Judith Butler sofre agressão no aeroporto de Congonhas". O Globo, 10/1 1/ 2017. Disponível em https://cutt.ly/LhaBQuv.

GUISASOLA, José Manuel Martínez. La ideología de género: génesis filosófica, desarrollo doctrinal e incursión jurídica. Sevilla/España: Punto Rojo Libros, 2018.

JUNQUEIRA, Rogério Diniz. "Ideologia de gênero: a gênese de uma categoria política reacionária ou a promoção dos direitos humanos se tornou uma ameaça à família natural?". In: RIBEIRO, Paula Regina Costa; MAGALHÃES, Joana Lira. Debates contemporâneos sobre educação para a sexualidade. Rio Grande: EDFURG, 2017.

JUNQUEIRA, Rogério Diniz. "A invenção da 'ideologia de gênero': a emergência de um cenário político-discursivo e a elaboração de uma retórica reacionária antigênero". Revista Psicol. Polít., São Paulo, v. 18, n. 43, p. 449-502, dez. 2018.

KUHAR, Roman; PATERNOTTE, David. Anti-gender campaigns in Europe: Mobilizing against equality. London: Rowman \& Littlefield International, 2018.

LARA, Bruna. "Entrevista: 'Quem é contra o aborto não dá um real pra criança quando nasce', diz Silvia Federici". The Intercept Brasil, 2019. Disponível em https://n9.cl/juupp. Acesso em 20/10/2019.

LEIRNER, Piero. "Contradições e bate-cabeça da campanha de Bolsonaro são intencionais". Entrevista a Gil Alessi. El País, 2018. Disponível em https://n9.cl/xgum. Acesso em 20/10/2019.

LÓPEZ, Jairo Antonio. "Movilización y contramovilización frente a los derechos LGBTI. Respuestas conservadoras al reconocimiento de los derechos humanos". Estudios Sociológicos, v. 36, n. 106, 2018.

LIMA, Jônatas. "1 18 entidades pró-vida e pró-família lançam nota pedindo Damares Alves como ministra". Gazeta do Povo, 2018. Disponível em https://cutt.ly/NhaVg4p. Acesso em 30/03/2020.

LÖWY, Michael. "Conservadorismo e extrema-direita na Europa e no Brasil". Serv. Soc. Soc., n. 124, p. 652-664, 2015.

LUNA, Naara. "A criminalização da 'ideologia de gênero': uma análise do debate sobre diversidade sexual na Câmara dos Deputados em 2015". Cadernos Pagu, n. 50, E175018, 2017.

MAIA, Tatiana Vargas. "A falsa dicotomia entre pautas identitárias e economia". El País, 2018. Disponível em https://n9.cl/ohnz. Acesso em 18/10/2019.

MANOEL, Jones. "O Bolsonarismo e a cortina de fumaça". Mídia Ninja, 2018. Disponível em https:/ /n9.cl/y64gs. Acesso em 18/10/2019. 
MÁRQUEZ, Nicolás; LAGE, Agustín. El libro negro de la nueva izquierda: ideología de género o subversión cultural. Buenos Aires: Unión, 2016.

MELO, Flávia. "O túnel, o Frota, a ideologia de gênero". Ponto Urbe, v. 1, 2016.

MELO, Flávia; CANDOTTI, Fabio Magalhães. "Por el derecho a la vida y a la familia: uma interpretação butleriana dos agenciamentos discursivos sobre ideologia de gênero na América Latina". In: SEMINÁRIO INTERNACIONAL FAZENDO GÊNERO 11 \& $13^{\circ}$ MUNDOS DE MULHERES, 2017, Florianópolis/SC. Anais do Seminário Internacional Fazendo Gênero 11 \& $13^{\circ}$ Mundos de Mulheres. Florianópolis/SC: UFSC, 2017.

MESSENBERG, Débora. "A direita que saiu do armário: a cosmovisão dos formadores de opinião dos manifestantes de direita brasileiros". Sociedade e Estado, v. 32, n. 3, 2017.

MIGUEL, Luis Felipe. "A reemergência da direita brasileira". In: MIGUEL, Luis Felipe (Org.). O ódio como política: a reinvenção da direita no Brasil. São Paulo: Boitempo, 2018. p. 17-26.

MIGUEL, Luis Felipe. "Da 'doutrinação marxista' à 'ideologia de gênero' - Escola sem partido e as leis da mordaça no parlamento brasileiro". Direito \& Práxis, v. 7, p. 15, 2016.

MISKOLCI, Richard; CAMPANA, Maximiliano. "Ideologia de gênero: notas para a genealogia de um pânico moral contemporâneo", Sociedade e Estado, v. 32, n. 3, 2017.

MISKOLCI, Richard; PEREIRA, Pedro Paulo. "Quem tem medo de Judith Butler? A cruzada moral contra os direitos humanos no Brasil". Cadernos Pagu, n. 53, 2018. ISSN 0104-8333

MORAIS, Raquel. "Morre Brilhante Ustra, ex-chefe do DOI-Codi durante a ditadura". G1, 15/10/2015. Disponível em https://n9.cl/6ffx. Acesso em 16/08/2019.

MOURA, Rafael Moraes; PUPO, Amanda. "STF se antecipa e Congresso julga pautas de costumes". Estadão, 2019. Disponível em https://n9.cl/jy3ko. Acesso em 18/10/2019.

MUELLE, Camila Esguerra. "Cómo hacer necropolíticas en casa: Ideología de género y acuerdos de paz en Colombia". Sexualidade, Saúde e Sociedade, n. 27, p. 172-198, 2017.

NASCIMENTO, Alcileide Cabral do. "A primavera feminista. Vozes de luta da emancipação feminina no Brasil e Uruguai". Revista Estudos Feministas, v. 26, n. 2, 2018.

O'LEARY, Dale. The gender agenda. Laffayette: Vital Issues Press, 1997.

PALACIOS, Ariel. "Da prisão ao casamento: as relações homoafetivas em nove países das Américas". Revista Época, 2019. Disponível em https://n9.cl/2†g7. Acesso em 18/10/2019.

PAPA BENTO XVI. "Discurso do Papa Bento XVI à Cúria Romana por ocasião dos votos de Feliz Natal", 2008. Disponível em https://n9.cl/gt6jq. Acesso em 20/10/2019.

PONTIFICIO CONSIGLIO PER LA FAMIGLIA. Lexicon: termini ambigui e discussi su famiglia, vita e questioni etiche. 2. ed. Bologna: Dehoniane, 2006.

PRADO, Marco Aurélio Maximo; CORRÊA, Sonia. "Retratos transnacionais e nacionais das cruzadas antigênero". Rev. Psicol. Polít., v. 18, n. 43, 2018.

PROJETO DE LEI. PL 3235, 2015. Autor: Pr. Marco Feliciano - PSC/SP. Ementa: Acrescenta o art. 234-A à Lei no 8.069, de 13 de julho de 1990, que "dispõe sobre o Estatuto da Criança e do Adolescente e dá outras providências". Brasil, 2015. Disponível em https://n9.cl/71zet. Acesso em 15/05/2019.

PROJETO DE LEI. PL 477, 2015. Autor: Eros Biondini - PTB/MG. Ementa: Altera os artigos $5^{\circ}$ e $8^{\circ}$ da Lei no 11.340 , de 7 de agosto de 2006, que cria mecanismos para coibir a violência doméstica e familiar contra a mulher, substituindo o termo gênero por sexo. Brasil, 2015. Disponível em https://n9.cl/6uun. Acesso em 04/09/2019.

PROETO DE LEI. PL 6055, 2013. Autor: Pastor Eurico - PSB/PE e outros. Ementa: Revoga-se a Lei no 12.845 , de $1^{\circ}$ de agosto de 2013 , que "dispõe sobre o atendimento obrigatório e integral, às pessoas vítimas de violência sexual". Brasília, 2013. Disponível em https://cutt.ly/bhsRG5k. Acesso em 04/09/2019.

RAMALHO, Renan. "Bolsonaro vira réu por falar que Maria do Rosário não merece ser estuprada". G1, 22/06/2016. Disponível em https://cutt.ly/vhaVxA4. Acesso em 16/08/2019. 
RATZINGER, Joseph Aloisius. La sal de la tierra. Madrid: Libros Palabra, 1997.

RIBEIRO, Letícia; O'DWYER, Brena; HEILBORN, Maria Luiza. "Dilemas do feminismo e a possibilidade de radicalização da democracia em meio às diferenças: o caso da Marcha das Vadias do Rio de Janeiro". Civitas, v. 18, n. 1, p. 83-99, 2018.

RINCÓN, Reyes. "Justiça espanhola eleva pena da 'Manada': foi estupro coletivo, não um abuso sexual". El País, 21/06/2019. Disponível em https://n9.cl/3tpee. Acesso em 20/10/2019.

RONDÓN, Manuel Alejandro Rodríguez. "La ideología de género como exceso: pánico moral y decisión ética en la política colombiana". Sexualidad, Salud \& Sociedad, n. 27, 2017.

RUBIN, Gayle. "Thinking sex. Notes for a radical theory of the politics of sexuality". In: ABELOVE, Henry; BARALE, Michele A.; HALPERIN, David M. (Eds.). The lesbian and gay studies reader. New York: Routledge, 1993.

SANCHEZ, Beatriz. "Mulheres, corpo e insurreição: uma análise das manifestações feministas no Brasil à luz da obra de Judith Butler". In: CONFERÊNCIA INTERNACIONAL IFJP - GENDER VIOLENCE AND FEMINIST RESISTANCE IN LATIN AMERICA. Anais... São Paulo, 2019.

SCALA, Jorge. La ideología de género: o el Género como herramienta de poder. Buenos Aires: Sekotia, 2010.

SEMANA. "Proponen 'frente latinoamericano' contra la ideología de género". Semana, 2016. Disponível em https://www.semana.com/nacion/. Acesso em 18/10/2019.

SENADO FEDERAL. Proposta de Emenda à Constituição n 6, de 2019. Atividade Legislativa. Brasília, 2019. Disponível em https://n9.cl/9yu07.

TEIXEIRA, Jacqueline Moraes. Pesquisadora Jacqueline Teixeira diz que projetos na Igreja Universal estimulam empreendedorismo feminino e 'domesticação' dos homens. 'Damares é muito forte dentro do Governo. Ela pode até cair, mas teria que sangrar muito antes'. In: ROSSI, Marina. "Para muitas mulheres o processo de empoderamento está atrelado à igreja". El País, 2019. Disponível em https://n9.cl/7u1c9. Acesso em 20/10/2019.

THINK OLGA. "Hashtag transformação: 82 mil tweets sobre \#PrimeiroAssédio". Artigos. Think Olga, 2015. Disponível em https://n9.cl/clqj.

VIGOYA, Mara Viveros; RONDÓN, Manuel Alejandro Rodríguez. "Hacer y deshacer la ideología de género". Sexualidad, Salud \& Sociedad, n. 27, 2017.

YOUTUBE. "Entrevista com o Deputado Givaldo Carimbão". YouTube, 10/09/2015. Disponível em https://youtu.be/cLfsEMj6XjO. Acesso em 12/05/2018.

YOUTUBE. "BOLSONARO NO DEBATE BAND. Participação completa". YouTube, 2018a. Disponível em https://youtu.be/TlaM2wNYjTQ. Acesso em 01/12/2018.

YOUTUBE. "Damares e o pé de goiaba". Reinaldo Azevedo. YouTube, 12/12/2018b. Disponível em https://youtu.be/dQk-QXsXGzs. Acesso em 20/10/2019.

YOUTUBE. "Angela Davis - Atravessando o tempo e construindo o futuro da luta contra o racismo". TVE Bahia. YouTube, 2017. Disponível em https://youtu.be/2vYZ4IJtgDO.

YOUTUBE. "Não quero sangue inocente em minhas mãos! Dra Damares Alves". YouTube, 15/07/ 2013. Disponível em https://youtu.be/MOuKszPzLK4. Acesso em 20/10/2019.

YOUTUBE. "Damares: 'Menino veste Azul e menina veste Rosa'. Uma Nova Era?". ATeuVer. YouTube, 2019. Disponível em https://youtu.be/6myjru-e81U. Acesso em 03/09/2019.

Flávia Melo (flaviamelo@ufam.edu.br) é doutora em Antropologia Social na Universidade de São Paulo. Mestre em Antropologia Social (Unicamp) e Bacharel em Ciências Sociais pela Universidade Federal do Amazonas, onde atua como Professora e pesquisadora desde 2009 nas áreas de Estudos de Gênero, Políticas Públicas e Fronteira. Criadora e coordenadora do Observatório da Violência de Gênero no Amazonas. Foi pesquisadora visitante na Universidade Complutense de Madri/Espanha. 
COMO CITAR ESSE ARTIGO DE ACORDO COM AS NORMAS DA REVISTA

MELO, Flávia. "Não é fumaça, é fogo! Cruzada antigênero e resistências feministas no Brasil". Revista Estudos Feministas, Florianópolis, v. 28, n. 3, e72564, 2020.

\section{CONTRIBUIÇÃO DE AUTORIA}

Não se aplica.

\section{FINANCIAMENTO}

Não se aplica.

\section{CONSENTIMENTO DE USO DE IMAGEM}

Não se aplica.

APROVAÇÃO DE COMITÊ DE ÉTICA EM PESQUISA

Não se aplica.

\section{CONFLITO DE INTERESSES}

Não se aplica.

\section{LICENÇA DE USO}

Este artigo está licenciado sob a Licença Creative Commons CC-BY Internacional. Com essa licença você pode compartilhar, adaptar, criar para qualquer fim, desde que atribua a autoria da obra.

\section{HISTÓRICO}

Recebido em 30/03/2020

Reapresentado em 24/07/2020

Aprovado em 17/08/2020 